\section{BRAZIULIAN JOURNAL}

OF MEDICAL AND BIOLOGICAL RESFARCH

www.bjournal.com.br
ISSN 0100-879X

Volume 44 (7) 606-728 July 2011

BIOMEDICAL SCIENCES

AND

CLINICAL INVESTIGATION

Braz J Med Biol Res, July 2011, Volume 44(7) 713-719

Prevalence of metabolic syndrome and its association with educational inequalities among Brazilian adults: a population-based study

M.F. Gronner, P.L. Bosi, A.M. Carvalho, G. Casale, D. Contrera, M.A. Pereira, T.M. Diogo,

M.T.C.G. Torquato, G.M.D. Souza, J. Oishi and A.M.O. Leal

The Brazilian Journal of Medical and Biological Research is partially financed by

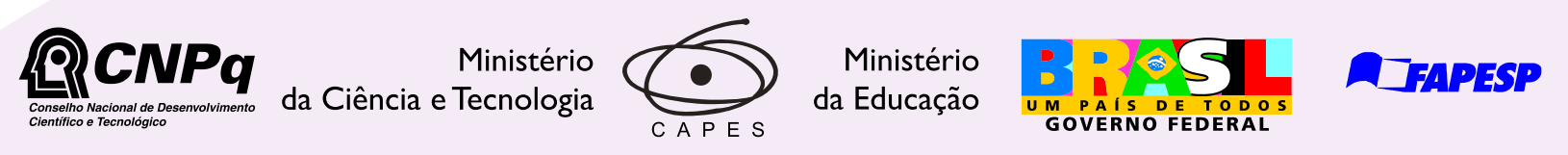

Institutional Sponsors
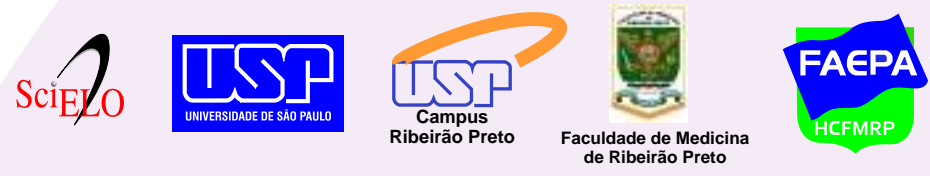

de Ribeirão Predic

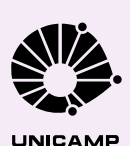

$\oplus$ SHIMADZU

GE Healthcare
Hotsite of proteomics metabolomics developped by:

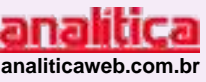

Thermo SCIEN T IFIC 


\title{
Prevalence of metabolic syndrome and its association with educational inequalities among Brazilian adults: a population-based study
}

\author{
M.F. Gronner ${ }^{1}$, P.L. Bosi², A.M. Carvalho1 ${ }^{1}$, G. Casale1, D. Contrera ${ }^{1}$, \\ M.A. Pereira1, T.M. Diogo ${ }^{1}$, M.T.C.G. Torquato ${ }^{1}$, G.M.D. Souza ${ }^{3}$, \\ J. Oishi ${ }^{3}$ and A.M.O. Leal ${ }^{1}$ \\ ${ }^{1}$ Departamento de Medicina, ${ }^{2}$ Departamento de Fisioterapia, ${ }^{3}$ Departamento de Estatística, \\ Universidade Federal de São Carlos, São Carlos, SP, Brasil
}

\begin{abstract}
The present study estimated the prevalence of metabolic syndrome (MS) according to the criteria established by the National Cholesterol Education Program-Adult Treatment Panel III (NCEP-ATPIII) and the International Diabetes Federation (IDF) and analyzed the contribution of social factors in an adult urban population in the Southeastern region of Brazil. The sample plan was based on multistage probability sampling according to family head income and educational level. A random sample of 1116 subjects aged 30 to 79 years was studied. Participants answered a questionnaire about socio-demographic variables and medical history. Fasting capillary glucose (FCG), total cholesterol, high-density lipoprotein cholesterol (HDL$\mathrm{C})$, and triglycerides were determined and all non-diabetic subjects were submitted to the 75-g oral glucose tolerance test. Body mass index (BMI, $\mathrm{kg} / \mathrm{m}^{2}$ ), waist circumference and blood pressure (BP) were determined. Age- and gender-adjusted prevalence of MS was 35.9 and $43.2 \%$ according to NCEP-ATPIII and IDF criteria, respectively. Substantial agreement was found between NCEP-ATPIII and IDF definitions. Low HDL-C levels and high BP were the most prevalent MS components according to NCEP-ATPIII criteria (76.3 and $59.2 \%$, respectively). Considering the diagnostic criteria adopted, $13.5 \%$ of the subjects had diabetes and $9.7 \%$ had FCG $\geq 100 \mathrm{mg} / \mathrm{dL}$. MS prevalence was significantly associated with age, skin color, $\mathrm{BMI}$, and educational level. This cross-sectional population-based study in the Southeastern region of Brazil indicates that MS is highly prevalent and associated with an important social indicator, i.e., educational level. This result suggests that in developing countries health policy planning to reduce the risk of MS, in particular, should consider improvement in education.
\end{abstract}

Key words: Metabolic syndrome; Prevalence; Brazil; Diabetes

\section{Introduction}

Metabolic syndrome (MS) is now widely accepted as a group of core cardiovascular risk factors that include central obesity, dyslipidemia, hyperglycemia, and hypertension independently of its evolving definitions and debate about the most appropriate method for identifying individuals at high risk for cardiovascular diseases (CVD) and diabetes (1-9). MS has become one of the major public health challenges worldwide because affected individuals have a 2- to 5-fold increased risk to develop type 2 diabetes mellitus and to suffer CVD-related mortality, leading to a great impact on

public health costs and planning (10-14).

Metabolic syndrome is widespread among adults from North America, Europe and Asia, and several reports of its prevalence in various populations have been published in recent years $(8,15-17)$, most of them in developed countries. However, population-based studies are still scarce in developing countries and in South America, especially in Brazil, the most populous country of the continent (18-21). Moreover, the impact of the use of different definitions of MS and cut-off points for MS components to estimate the preva-

Correspondence: A.M.O. Leal, Departamento de Medicina, Universidade Federal de São Carlos, Rod. Washington Luís, km 235, 13565-905 São Carlos, SP, Brasil. Fax: 55-16-3351-8340. E-mail: angelaleal@ufscar.br

Received January 21, 2011. Accepted June 14, 2011. Available online July 8, 2011. Published July 25, 2011. 
lence of MS in different populations is unclear. In addition, specific demographic and social factors may have diverse impacts on health conditions in different countries.

The objective of the present study was to estimate the prevalence of MS according to the criteria established by both the revised National Cholesterol Education ProgramAdult Treatment Panel III (NCEP-ATPIII) and the International Diabetes Federation (IDF) and to analyze contributing factors in an urban population from the Southeastern region of Brazil.

\section{Material and Methods}

\section{Sampling procedure}

A population-based cross-sectional home survey was performed from August 2007 to June 2008 in the adult urban population of São Carlos, a medium-size city in the State of São Paulo, Southeastern region of Brazil. The sampling plan was based on a multistage stratified design according to the income and educational level of the family head and on data from the Brazilian Institute of Geography and Statistics (IBGE) (22) and the State Foundation System for Data Analysis (SEADE) (23). To calculate the sample size, the Normal model was adopted as reference and a sample size mathematical formula was used to estimate population means assuming estimated variance of glycemia, a $95 \%$ confidence interval and a maximum error of 3 . The final number accounted for $5 \%$ losses.

The population was encouraged to participate in the study through the local media. Only subjects who agreed to participate and signed the consent form were included in the study. Exclusion criteria were pregnant women and physically or mentally disabled persons unable to understand simple questions and to provide a blood sample.

The study was approved by the Ethics Committee of Universidade Federal de São Carlos and all participants gave written informed consent.

\section{Study design}

The survey was conducted by trained health care graduate students on two consecutive days. On the first day, those who agreed to participate in the study were informed about the need for a 10- to 12-h fast and answered a questionnaire requesting information about socio-demographic variables and medical history in face-to-face interviews. Skin color was self-defined as one of two categories, i.e., white or non-white, and income was categorized according to the number of national minimum wages. Schooling was classified as fundamental (elementary school), middle (high school) or higher (university). Smoking status was classified as yes or no.

On the second day, fasting capillary glucose (FCG), highdensity lipoprotein cholesterol (HDL-C) and triglycerides (TG) were determined with a portable device (CardioChek ${ }^{\circledR}$, Polymer Technology Systems, USA). All non-diabetic subjects (FCG $<200 \mathrm{mg} / \mathrm{dL}$ and no treatment for diabetes) were submitted to the 75-g oral glucose tolerance test and classified as diabetic if $2-\mathrm{h}$ capillary glycemia $\geq 200 \mathrm{mg} / \mathrm{dL}$ (2). Height and weight were measured with the subject barefoot using a non-stretchable measuring tape and a portable electronic scale, respectively, and body mass index $\left(\mathrm{BMI}, \mathrm{kg} / \mathrm{m}^{2}\right)$ was calculated. Waist circumference $(\mathrm{cm})$ was measured twice midway between the lower rib margin and the iliac crest and the mean value was recorded. Blood pressure $(\mathrm{BP}, \mathrm{mmHg}$ ) was measured three times with an electronic device $\left(\mathrm{OMRON}^{\circledR}\right)$ on three different occasions and the mean value was used. Before beginning the study, we compared the results obtained from standard laboratory assays and from the method of simultaneously collected blood samples used, and the agreement between values was sufficiently close. Fieldwork supervisors verified the quality control of physical examination and questionnaire application.

\section{Diagnostic criteria}

According to the updated 2005 ATPIII criteria (7), MS was diagnosed when the participant had three or more of the following characteristics: 1) waist circumference $>102 \mathrm{~cm}$ in men and $>88 \mathrm{~cm}$ in women; 2) pharmacologic hypertension treatment or $\mathrm{BP} \geq 130 / 85 \mathrm{mmHg}$; 3 ) TG $\geq 150$ $\mathrm{mg} / \mathrm{dL}(1.7 \mathrm{mM})$ or use of medication; 4) HDL-C, $<40$ in men $(1.03 \mathrm{mM})$ and $<50(1.29 \mathrm{mM})$ in women or use of medication; 5) fasting glycemia $\geq 100 \mathrm{mg} / \mathrm{dL}$ (5.6 mM) or diabetes mellitus type 2 . According to IDF criteria (6), MS was diagnosed when the participant had elevated waist circumference ( $\geq 90 \mathrm{~cm}$ in men and $\geq 80 \mathrm{~cm}$ in women) plus any two of the components cited above.

\section{Statistical analysis}

The information collected was entered into a data bank and analyzed using the SAS/STAT software (SAS Institute Inc., USA). Prevalences were adjusted by gender and age by a direct method, using as standard the population of São Carlos from the 2000 Brazilian demographic census (22). We applied logistic regression analysis to assess the association between MS and social-demographic and life-style factors. The Fisher exact test was applied to test for differences in proportions of categorical variables. Agreement between NCEP-ATPIII and IDF definitions was evaluated by the $\mathrm{K}$ statistic. $\mathrm{P}<0.05$ was considered to be statistically significant.

\section{Results}

A random sample of 1116 subjects aged 30 to 79 years was studied. The rate of refusal to participate was $4.5 \%$. According to NCEP-ATPIII criteria, $38 \%$ of women and $35.7 \%$ of men had MS. According to IDF criteria, MS was present in $45.5 \%$ of women and in $45.3 \%$ of men. The age and gender-adjusted general prevalence of MS was 35.9 
and $43.2 \%$ according to NCEP-ATPIII and IDF, respectively (Table 1). Substantial agreement $[K=0.80,95 \%$ confidence interval $(\mathrm{Cl})=0.77-0.84]$ was found between NCEP-ATPIII and IDF definitions.

Table 2 shows data about the prevalence of MS components. Low levels of HDL-C (mean \pm SD, $26.7 \pm 7.5 \mathrm{mg} / \mathrm{dL})$ were the most prevalent MS component (76.3\%). According to gender, $78 \%$ of men and $75.4 \%$ of women had low levels of HDL-C. Increased TG levels were present in $16.8 \%$ of subjects (mean $\pm \mathrm{SD}, 251.2 \pm 106.5 \mathrm{mg} / \mathrm{dL}$ ). High BP was the second most prevalent MS component in men, identified in $64.6 \%$ of men and in $56.3 \%$ of women. Considering

Table 1. Prevalence of metabolic syndrome according to age and gender in an urban population aged 30-79 years in the Southeastern region of Brazil.

\begin{tabular}{|c|c|c|c|c|c|c|}
\hline \multirow[t]{2}{*}{ Age groups (years) } & \multicolumn{2}{|c|}{$\operatorname{Men}(N=396)$} & \multicolumn{2}{|c|}{ Women $(\mathrm{N}=720)$} & \multicolumn{2}{|c|}{ Total $(\mathrm{N}=1116)$} \\
\hline & NCEP & IDF & NCEP & IDF & NCEP & IDF \\
\hline $30-39$ & $19(13.3)$ & $29(14.9)$ & $28(9.1)$ & $34(9.9)$ & $47(10.4)$ & $63(11.7)$ \\
\hline $40-49$ & $26(18.2)$ & $37(19.0)$ & $67(21.7)$ & $74(21.6)$ & $93(20.6)$ & $111(20.7)$ \\
\hline $50-59$ & $43(30.1)$ & $47(24.1)$ & $84(27.2)$ & $93(27.2)$ & $127(28.1)$ & $140(26.1)$ \\
\hline $60-69$ & $35(24.5)$ & $47(24.1)$ & $63(20.4)$ & $70(20.5)$ & $98(21.7)$ & $117(21.8)$ \\
\hline $70-79$ & $20(14.0)$ & $35(18.0)$ & $67(21.7)$ & $71(20.8)$ & 87 (19.3) & $106(19.7)$ \\
\hline Total & $143(36.1)$ & $195(49.2)$ & 309 (42.9) & $342(47.5)$ & $452(40.5)$ & $537(48.1)$ \\
\hline $\begin{array}{l}\text { Age- and gender-adjusted } \\
\text { prevalence }(95 \% \mathrm{Cl})\end{array}$ & $35.7(25.2-46.2)$ & $45.3(40.4-50.2)$ & $38.0(27.4-48.6)$ & $45.5(40.6-50.4)$ & $35.9(25.4-46.4)$ & $43.2(38.3-48.1)$ \\
\hline
\end{tabular}

Data are reported as number with percent in parentheses. $\mathrm{Cl}=$ confidence interval; NCEP $=$ National Cholesterol Education ProgramAdult Treatment Panel III; IDF = International Diabetes Federation.

Table 2. Prevalence of metabolic syndrome components according to age and gender in an urban population aged 30-79 years in the Southeastern region of Brazil.

\begin{tabular}{|c|c|c|c|c|c|c|}
\hline $\begin{array}{l}\text { Age groups } \\
\text { (years) }\end{array}$ & $\begin{array}{l}\text { Fasting glycemia } \\
\geq 100 \mathrm{mg} / \mathrm{dL} \text { or } \mathrm{DM}\end{array}$ & $\begin{array}{l}\text { Wc (NCEP criteria) } \\
>102 \text { (men) or } 88 \\
\text { cm (women) }\end{array}$ & $\begin{array}{l}\text { Wc (IDF criteria) } \\
\geq 90 \text { (men) or } 80 \\
\text { cm (women) }\end{array}$ & $\begin{array}{c}\text { Blood pressure } \geq 130 / 85 \\
\text { mmHg or anti-hypertensive } \\
\text { medication }\end{array}$ & $\begin{array}{l}\text { HDL-C levels } \\
<40 \text { (men) or } 50 \\
\mathrm{mg} / \mathrm{dL} \text { (women) }\end{array}$ & $\begin{array}{l}\text { TG levels } \\
\geq 150 \\
\mathrm{mg} / \mathrm{dL}\end{array}$ \\
\hline \multicolumn{7}{|c|}{ Men $(N=396)$} \\
\hline $30-39$ & $4(9.3)$ & $20(13.5)$ & $46(18.6)$ & $38(14.8)$ & $67(21.7)$ & 18 (20.9) \\
\hline $40-49$ & $8(18.6)$ & $25(16.9)$ & $40(16.2)$ & $47(18.4)$ & $69(22.3)$ & $20(23.3)$ \\
\hline $50-59$ & $13(30.2)$ & $43(29.0)$ & $69(27.9)$ & $68(26.6)$ & $72(23.3)$ & $27(31.4)$ \\
\hline $60-69$ & $11(25.6)$ & $37(25.0)$ & $51(20.6)$ & $55(21.5)$ & $54(17.5)$ & $13(15.1)$ \\
\hline $70-79$ & $7(16.3)$ & $23(15.5)$ & $41(16.6)$ & $48(18.8)$ & $47(15.2)$ & $8(9.3)$ \\
\hline Total & $43(10.9)$ & $148(37.4)$ & $247(62.4)$ & $256(64.6)$ & 309 (78) & $86(21.7)$ \\
\hline$P$ value & 0.22 & $<0.01$ & $<0.01$ & $<0.01$ & 0.30 & 0.27 \\
\hline \multicolumn{7}{|c|}{ Women $(\mathrm{N}=720)$} \\
\hline $30-39$ & $6(5.7)$ & $87(18.2)$ & $112(19.9)$ & $45(11.1)$ & $111(20.4)$ & $12(11.8)$ \\
\hline $40-49$ & $18(17.1)$ & $107(22.3)$ & $123(21.8)$ & $82(20.3)$ & $127(23.4)$ & $26(25.5)$ \\
\hline $50-59$ & $34(32.4)$ & $122(25.5)$ & $147(26.1)$ & $107(26.4)$ & $145(26.7)$ & $26(25.5)$ \\
\hline $60-69$ & $21(20.0)$ & $85(17.8)$ & $97(17.2)$ & $85(21.0)$ & $85(15.7)$ & $17(16.7)$ \\
\hline $70-79$ & $26(24.8)$ & 78 (16.3) & $84(14.9)$ & $86(21.2)$ & $75(13.8)$ & $21(20.6)$ \\
\hline Total & $105(14.6)$ & $479(66.5)$ & $563(78.2)$ & 405 (56.3) & $543(75.4)$ & $102(14.2)$ \\
\hline$P$ value & $<0.01$ & 0.02 & 0.15 & $<0.01$ & 0.46 & 0.06 \\
\hline Total & 148 (13.3) & $627(56.2)$ & $810(72.6)$ & $661(59.2)$ & $852(76.3)$ & $188(16.8)$ \\
\hline
\end{tabular}

Data are reported as number with percent in parentheses. The Fisher exact test was used for statistical analysis. NCEP $=$ National Cholesterol Education Program-Adult Treatment Panel III; IDF = International Diabetes Federation; DM = diabetes mellitus; Wc = waist circumference; HDL-C = high-density lipoprotein cholesterol; TG = triglycerides. 
the diagnostic criteria adopted, $13.5 \%$ of the subjects had diabetes mellitus and $9.7 \%$ had $F G \geq 100 \mathrm{mg} / \mathrm{dL}$. According to NCEP-ATPIII criteria, increased waist circumference was almost twice more frequent in women $(66.5 \%)$ than in men $(37.4 \%)$. According to IDF criteria, $78.2 \%$ of women and $62.4 \%$ of men had increased waist circumference and this was the most prevalent MS component in women.

Prevalence of MS according to IDF criteria was significantly associated with age, skin color, BMI, and educational level, as estimated by age/gender and skin color-adjusted odds ratio (OR) and logistic regression analysis (Table 3). No association was observed between MS and gender, family income or smoking status. Educational level was significantly associated with MS components, hyperglycemia, increased waist circumference and hypertension in women (Table 4).

The differences in the number of men and women between Tables 2 and 4 are related to the fact that some individuals did not answer the specific question about their educational level. Regarding the difference between the number of women and men in the study, men were not at home at the time of the interview or refused to participate more frequently than women.

\section{Discussion}

The prevalence of MS in an urban Brazilian population was high, varied according to the criteria adopted and was associated with an important social indicator, i.e., educational level.

Comparisons of published prevalence rates for different populations are difficult. In Latin America, the prevalence of MS among adults ranges from 20 to $50 \%$ depending on the age group, gender and particular characteristics of the population studied $(18,19,24,25)$. In Brazil, data from most epidemiological studies are restricted to specific population groups (20,26-30), a fact that impairs comparisons. The MS prevalence observed in the present study is higher than

Table 3. Estimated crude and age/gender/skin color-adjusted odds ratio (OR) of metabolic syndrome prevalence according to IDF criteria in relation to different levels of demographic-related factors in an urban population aged $30-79$ years in the Southeastern region of Brazil.

\begin{tabular}{|c|c|c|c|}
\hline Characteristics & $N(\%)$ & Crude OR $(95 \% \mathrm{Cl})$ & Age/gender/skin color-adjusted OR $(95 \% \mathrm{Cl})$ \\
\hline \multicolumn{4}{|c|}{ Age groups (years) } \\
\hline $30-39$ & $63(11.73)$ & reference & reference \\
\hline $40-49$ & $111(20.67)$ & $2.15(1.47-3.16)$ & - \\
\hline $50-59$ & $140(26.07)$ & $2.68(1.85-3.89)$ & - \\
\hline $60-69$ & $117(21.79)$ & $4.64(3.06-7.04)$ & - \\
\hline $70-79$ & $106(19.74)$ & $4.77(3.11-7.32)$ & - \\
\hline \multicolumn{4}{|l|}{ Gender } \\
\hline Female & $342(63.69)$ & reference & reference \\
\hline Male & $195(36.31)$ & $1.07(0.84-1.37)$ & - \\
\hline \multicolumn{4}{|l|}{ Skin color } \\
\hline Non-white & $145(27.57)$ & reference & reference \\
\hline White & $381(72.43)$ & $1.65(1.28-2.14)$ & - \\
\hline \multicolumn{4}{|c|}{ Family income (minimal national wages) } \\
\hline$<2$ & $93(19.14)$ & reference & reference \\
\hline $2-5$ & $286(58.85)$ & $1.31(0.82-1.56)$ & $1.18(0.84-1.66)$ \\
\hline $5-10$ & $86(17.70)$ & $0.99(0.66-1.48)$ & $0.92(0.61-1.41)$ \\
\hline$>10$ & $21(4.32)$ & $0.64(0.35-1.16)$ & $0.57(0.30-1.07)$ \\
\hline \multicolumn{4}{|l|}{ Educational level } \\
\hline Higher & $29(6.09)$ & reference & reference \\
\hline Middle & 94 (19.75) & $1.38(0.83-2.30)$ & $1.64(0.96-2.80)$ \\
\hline Fundamental & $353(74.16)$ & $2.51(1.58-4.00)$ & $2.41(1.47-3.96)$ \\
\hline \multicolumn{4}{|l|}{ Smoking } \\
\hline No & $421(79.73)$ & $1.25(0.94-1.66)$ & $1.10(0.81-1.48)$ \\
\hline Yes & $107(20.27)$ & reference & reference \\
\hline \multicolumn{4}{|l|}{ BMI } \\
\hline$<25$ & $90(16.76)$ & reference & reference \\
\hline$\geq 25$ & $447(83.24)$ & $5.68(4.30-7.51)$ & $6.33(4.68-8.54)$ \\
\hline
\end{tabular}

IDF = International Diabetes Federation; BMI = body mass index. 
Table 4. Prevalence of metabolic syndrome components according to educational level among men and women of an urban population aged 30-79 years in the Southeastern region of Brazil.

\begin{tabular}{|c|c|c|c|c|c|}
\hline & $\begin{array}{l}\text { Fasting glycemia } \\
\geq 100 \mathrm{mg} / \mathrm{dL} \text { or } \mathrm{DM}\end{array}$ & $\begin{array}{l}\text { Waist circumference } \\
\text { (IDF criteria) >90 (men) } \\
\text { or } 80 \mathrm{~cm} \text { (women) }\end{array}$ & $\begin{array}{c}\text { Blood pressure } \geq 130 / 85 \\
\text { mmHg or anti-hypertensive } \\
\text { medication }\end{array}$ & $\begin{array}{l}\text { HDL-C levels } \\
<40 \text { (men) or } 50 \\
\mathrm{mg} / \mathrm{dL} \text { (women) }\end{array}$ & $\begin{array}{c}\text { TG levels } \geq 150 \\
\mathrm{mg} / \mathrm{dL}\end{array}$ \\
\hline \multicolumn{6}{|l|}{ Men $(N=356)$} \\
\hline \multicolumn{6}{|l|}{ Educational level } \\
\hline Fundamental & $24(60)$ & $161(64.7)$ & $151(67.1)$ & $178(64.5)$ & $52(66.7)$ \\
\hline Middle & $11(27.5)$ & $64(25.7)$ & $54(24.0)$ & $74(26.8)$ & $20(25.6)$ \\
\hline Higher & $5(12.5)$ & $24(9.6)$ & $20(8.9)$ & $24(8.7)$ & $6(7.7)$ \\
\hline Total & 40 & 249 & 225 & 276 & 78 \\
\hline$P$ value & 0.66 & 0.87 & 0.31 & 0.75 & 0.87 \\
\hline \multicolumn{6}{|l|}{ Women $(N=644)$} \\
\hline \multicolumn{6}{|l|}{ Educational level } \\
\hline Fundamental & $75(83.3)$ & $383(69.9)$ & $264(74.4)$ & $334(69.2)$ & $72(75.8)$ \\
\hline Middle & $11(12.2)$ & $119(21.7)$ & $67(18.9)$ & $110(22.8)$ & $17(17.9)$ \\
\hline Higher & $4(4.4)$ & $46(8.4)$ & $24(6.8)$ & $39(8.1)$ & $6(6.3)$ \\
\hline Total & 90 & 548 & 355 & 483 & 95 \\
\hline$P$ value & $<0.01$ & $<0.01$ & $<0.01$ & 0.14 & 0.19 \\
\hline
\end{tabular}

The Fisher exact test was used for statistical analysis. IDF = International Diabetes Federation; $D M=$ diabetes mellitus; HDL-C = highdensity lipoprotein cholesterol; TG = triglyceride.

recently reported, a fact that may be attributable to the lower age of the group studied in 1999-2000, which included people from 25 to 64 years of age (21). The prevalence of MS in Brazil is relatively high compared to the prevalence reported for the US and Europe (17) and the results confirm the consistent finding of age-dependency of MS prevalence as reported in most of the populations studied (12).

The higher prevalence of MS observed according to the IDF definition than according to the NCEP-ATPIII definition has been reported in different populations $(15,31,32)$. The difference between these two definitions is the lower cut-off point for waist circumference and the mandatory presence of central obesity for the diagnosis of MS by the IDF definition. The importance of waist circumference in the definition of MS and the identification of a larger segment of the population at increased risk for mortality by IDF criteria have been demonstrated by Katzmarzyk et al. (33) in a large sample of men. A lower cut-off for waist circumference has been proposed as a better criterion for the diagnosis of central obesity in Brazil (34).

The association of MS and cardiovascular disease with socioeconomic inequalities has been shown worldwide in different populations (35-37). A higher risk of developing MS has been recently shown among poorer Brazilian women (21). In the present study, the prevalence of MS was associated with educational level but not with family income. Educational level is considered to be a reliable and relevant indicator of social position especially regarding women, whose educational achievements are not rewarded with a higher income $(23,37-38)$. MS prevalence was also associ- ated with skin color. Coincidentally, in Brazil the non-white population attains a lower educational level than the white population (23). However, the great miscegenation of the Brazilian population should be pointed out. Moreover, in the present study, skin color was self-defined.

The biological basis for the association with educational disparities in MS remains unclear. It has been suggested that socioeconomic position influences nutritional and sedentary habits that are highly associated with MS components (39). Others have suggested that psychosocial stress could induce the secretion of hypothalamic-pituitary-adrenal axis hormones related to the development of MS (40).

The present study is limited by its cross-sectional design that does not allow the establishment of causal relations. One difficulty encountered by the research group in particular was the lower adhesion of men compared to women in the study.

In conclusion, this cross-sectional study conducted on an adult urban Brazilian population indicates that MS is highly prevalent and associated with an important social indicator, i.e., educational level. In developing countries, the health planning to prevent MS in particular should include improvement in the education of the population and should concentrate efforts on more comprehensible and effective strategies to guarantee that health information will reach all the strata of the population.

\section{Acknowledgments}

Research supported by FAPESP and CNPq. 


\section{References}

1. Reaven GM. Banting lecture 1988. Role of insulin resistance in human disease. Diabetes 1988; 37: 1595-1607.

2. World Health Organization. Definition, diagnosis and classification of diabetes mellitus and its complications. Part 1. Diagnosis and classification of diabetes mellitus. Geneva: WHO; 1999

3. Balkau B, Charles MA. Comment on the provisional report from the WHO consultation. European Group for the Study of Insulin Resistance (EGIR). Diabet Med 1999; 16: 442-443.

4. Executive Summary of the Third Report of the National Cholesterol Education Program (NCEP) Expert Panel on Detection, Evaluation, and Treatment of High Blood Cholesterol in Adults (Adult Treatment Panel III). JAMA 2001; 285: 2486-2497.

5. Einhorn D, Reaven GM, Cobin RH, Ford E, Ganda OP, Handelsman Y, et al. American College of Endocrinology position statement on the insulin resistance syndrome. Endocr Pract 2003; 9: 237-252.

6. Alberti KG, Zimmet P, Shaw J. The metabolic syndrome - a new worldwide definition. Lancet 2005; 366: 1059-1062.

7. Grundy SM, Brewer HB Jr, Cleeman JI, Smith SC Jr, Lenfant C. Definition of metabolic syndrome: Report of the National Heart, Lung, and Blood Institute/American Heart Association conference on scientific issues related to definition. Circulation 2004; 109: 433-438.

8. Desroches S, Lamarche B. The evolving definitions and increasing prevalence of the metabolic syndrome. Appl Physiol Nutr Metab 2007; 32: 23-32.

9. Isomaa B, Almgren P, Tuomi T, Forsen B, Lahti K, Nissen $\mathrm{M}$, et al. Cardiovascular morbidity and mortality associated with the metabolic syndrome. Diabetes Care 2001; 24: 683689.

10. Alberti KG, Eckel RH, Grundy SM, Zimmet PZ, Cleeman JI, Donato KA, et al. Harmonizing the metabolic syndrome: a joint interim statement of the International Diabetes Federation Task Force on Epidemiology and Prevention; National Heart, Lung, and Blood Institute; American Heart Association; World Heart Federation; International Atherosclerosis Society; and International Association for the Study of Obesity. Circulation 2009; 120: 1640-1645.

11. Lakka HM, Laaksonen DE, Lakka TA, Niskanen LK, Kumpusalo E, Tuomilehto J, et al. The metabolic syndrome and total and cardiovascular disease mortality in middle-aged men. JAMA 2002; 288: 2709-2716.

12. Eckel RH, Grundy SM, Zimmet PZ. The metabolic syndrome. Lancet 2005; 365: 1415-1428.

13. Wannamethee SG, Shaper AG, Lennon L, Morris RW. Metabolic syndrome vs Framingham Risk Score for prediction of coronary heart disease, stroke, and type 2 diabetes mellitus. Arch Intern Med 2005; 165: 2644-2650.

14. Wilson PW, D'Agostino RB, Parise H, Sullivan L, Meigs JB. Metabolic syndrome as a precursor of cardiovascular disease and type 2 diabetes mellitus. Circulation 2005; 112: 3066-3072.

15. Ford ES. Prevalence of the metabolic syndrome defined by the International Diabetes Federation among adults in the U.S. Diabetes Care 2005; 28: 2745-2749.

16. Grundy SM. Metabolic syndrome pandemic. Arterioscler Thromb Vasc Biol 2008; 28: 629-636.
17. Kolovou GD, Anagnostopoulou KK, Salpea KD, Mikhailidis DP. The prevalence of metabolic syndrome in various populations. Am J Med Sci 2007; 333: 362-371.

18. Aguilar-Salinas CA, Rojas R, Gomez-Perez FJ, Valles V, Rios-Torres JM, Franco A, et al. Analysis of the agreement between the World Health Organization criteria and the National Cholesterol Education Program-III definition of the metabolic syndrome: results from a population-based survey. Diabetes Care 2003; 26: 1635.

19. Florez H, Silva E, Fernandez V, Ryder E, Sulbaran T, Campos $\mathrm{G}$, et al. Prevalence and risk factors associated with the metabolic syndrome and dyslipidemia in White, Black, Amerindian and Mixed Hispanics in Zulia State, Venezuela. Diabetes Res Clin Pract 2005; 69: 63-77.

20. Freire RD, Cardoso MA, Gimeno SG, Ferreira SR. Dietary fat is associated with metabolic syndrome in Japanese Brazilians. Diabetes Care 2005; 28: 1779-1785.

21. Marquezine GF, Oliveira CM, Pereira AC, Krieger JE, Mill JG. Metabolic syndrome determinants in an urban population from Brazil: social class and gender-specific interaction. Int J Cardiol 2008; 129: 259-265.

22. IBGE. Instituto Brasileiro de Geografia e Estatística. http:// ibge.gov.br. Accessed December, 2009.

23. SEADE. Fundação Sistema Estadual de Análise de Dados. http://seade.gov.br. Accessed December 2009.

24. Ramirez-Vargas E, Arnaud-Vinas MR, Delisle H. Prevalence of the metabolic syndrome and associated lifestyles in adult males from Oaxaca, Mexico. Salud Publica Mex 2007; 49: 94-102.

25. Tull ES, Thurland A, LaPorte RE. Metabolic syndrome among Caribbean-born persons living in the U.S. Virgin Islands. Rev Panam Salud Publica 2005; 18: 418-426.

26. Rosenbaum P, Gimeno SG, Sanudo A, Franco LJ, Ferreira $\mathrm{SR}$. Analysis of criteria for metabolic syndrome in a population-based study of Japanese-Brazilians. Diabetes Obes Metab 2005; 7: 352-359.

27. Pousada JM, Britto MM, Cruz T, Lima ML, Lessa I, Lemaire DC, et al. The metabolic syndrome in Spanish migrants to Brazil: unexpected results. Diabetes Res Clin Pract 2006; 72: $75-80$.

28. Leite ML, Nicolosi A, Firmo JO, Lima-Costa MF. Features of metabolic syndrome in non-diabetic Italians and Brazilians: a discriminant analysis. Int J Clin Pract 2007; 61: 32-38.

29. Petri Nahas EA, Padoani NP, Nahas-Neto J, Orsatti FL, Tardivo AP, Dias R. Metabolic syndrome and its associated risk factors in Brazilian postmenopausal women. Climacteric 2009; 12: 431-438.

30. Dalacorte RR, Reichert CL, Vieira JL. Metabolic syndrome and physical activity in southern Brazilian communitydwelling elders: a population-based, cross-sectional study. BMC Public Health 2009; 9: 25.

31. Sandhofer A, Iglseder B, Paulweber B, Ebenbichler CF, Patsch JR. Comparison of different definitions of the metabolic syndrome. Eur J Clin Invest 2007; 37: 109-116.

32. Benner A, Zirie M, Mussallam M, Khader YS, Al-Hamaq AOAA. Prevalence of metabolic syndrome according to Adult Treatment Panel III and International Diabetes Federation criteria: A population-based study. Metabol Synd Relat Desord 2009; 7: 221-230. 
33. Katzmarzyk PT, Janssen I, Ross R, Church TS, Blair SN. The importance of waist circumference in the definition of metabolic syndrome: prospective analyses of mortality in men. Diabetes Care 2006; 29: 404-409.

34. Barbosa PJ, Lessa I, de Almeida FN, Magalhaes LB, Araujo J. Criteria for central obesity in a Brazilian population: impact on metabolic syndrome. Arq Bras Cardiol 2006; 87: 407414.

35. Park YW, Zhu S, Palaniappan L, Heshka S, Carnethon MR, Heymsfield SB. The metabolic syndrome: prevalence and associated risk factor findings in the US population from the Third National Health and Nutrition Examination Survey, 1988-1994. Arch Intern Med 2003; 163: 427-436.

36. Kim MH, Kim MK, Choi BY, Shin YJ. Educational disparities in the metabolic syndrome in a rapidly changing society - the case of South Korea. Int J Epidemiol 2005; 34: 1266-1273.

37. Silventoinen K, Pankow J, Jousilahti P, Hu G, Tuomilehto $\mathrm{J}$. Educational inequalities in the metabolic syndrome and coronary heart disease among middle-aged men and women. Int J Epidemiol 2005; 34: 327-334.

38. Bobak M, Hertzman C, Skodova Z, Marmot M. Own education, current conditions, parental material circumstances, and risk of myocardial infarction in a former communist country. J Epidemiol Community Health 2000; 54: 91-96.

39. Booth SL, Sallis JF, Ritenbaugh C, Hill JO, Birch LL, Frank LD, et al. Environmental and societal factors affect food choice and physical activity: rationale, influences, and leverage points. Nutr Rev 2001; 59: S21-S39.

40. Bjorntorp P, Rosmond R. The metabolic syndrome - a neuroendocrine disorder? Br J Nutr 2000; 83 (Suppl 1): S49-S57. 